\title{
Presumption of Innocence - A Criminal Procedural Guarantee as A Component of the System
}

\author{
Dildora Bazarova \\ $\mathrm{PhD}$, Head Of Department Of Criminal-Procedural Law \\ Of Tashkent State University Of Law, Uzbekistan
}

\begin{abstract}
This article discloses the presumption of innocence - a criminal procedural guarantee as a component of the system. The presumption of innocence is one of the basic constitutional principles that guarantee human rights and freedoms, which means that a person is presumed innocent until proven guilty in accordance with the procedure established by law and a court that has the right to initiate a criminal case.
\end{abstract}

Key words: criminal process, information in electronic view, proof, law, information, technology.

\section{Introduction}

Today, on the basis of conceptual reforms carried out by our state in various spheres of social life, it is important to improve our national legislation on the basis of the principle "Human, his rights and freedoms are a priority". Legal and regulatory documents related to criminal proceedings, which is one of the main areas of our national legislation, and aimed at ensuring the principles of the rule of law, equality of citizens before the law, the presumption of humanity, justice and innocence.

In order to ensure constitutional principles such as the rule of law, equality of citizens before the law, the presumption of humanity, justice and innocence, strict adherence to the requirements of relevant legislation has been identified as a priority for the judiciary and law enforcement agencies.

The principle of the presumption of innocence is one of the basic constitutional principles that guarantee human rights and freedoms, which means that a person is presumed innocent until proven guilty in accordance with the procedure established by law and a court that has the right to initiate a criminal case.

The presumption of innocence serves as a guarantee for the accused not only against unfounded accusations, but also against conviction. The requirement that his guilt be finally proven, and that doubts that cannot be resolved be resolved in favor of the accused, prompts the state authorities to determine the circumstances of the case in an impartial and fair manner, without which the case cannot be resolved reasonably and fairly in court.

The theory of criminal law defines the concept of "guilt" as "a deliberate or careless manifestation of a person's psychological attitude to a socially dangerous act (action or inaction) provided for by the Criminal Code, and its socially dangerous consequences committed by a person.

The presumption of innocence was first proclaimed in world history in the Declaration of Civil and Human Rights of the French State of August 26, 1789 as a procedural guarantee of the personal freedom of a citizen. In particular, Article 9 of this Declaration states that no one can be considered guilty until proven guilty. 
In addition, this concept is enshrined in the relevant norms of internationally recognized instruments such as the Universal Declaration of Human Rights, the International Covenant on Civil and Political Rights and the Convention for the Protection of Human Rights and Fundamental Freedoms.

\section{Main Part}

In particular, Article 11 of the Universal Declaration of Human Rights states that "everyone charged with a criminal offense has the right to be presumed innocent until proven guilty in accordance with the law in a public trial", and Article 14 of the International Covenant on civil and civil rights Political rights. "Any person charged with a crime has the right to be presumed innocent until proven guilty in accordance with the law."

In addition, our national legislation establishes the appropriate rules regarding the presumption of innocence, which serve to ensure the priority and guarantee of the individual, his rights and freedoms in our country.

In particular, the presumption of innocence is enshrined in article 26 of the Constitution of Uzbekistan, the content of which reads:

firstly, the case of any person accused of committing a crime cannot be considered guilty until it is considered lawfully, publicly and his guilt is not established;

secondly, all conditions will be created for the accused to be defended in court.

The norm of the presumption of innocence is set forth in Article 10 of the new Law of the Republic of Uzbekistan "On Courts" until the defendant is found guilty in accordance with the law and a court verdict that has entered into legal force.

A suspect, accused or defendant is considered innocent until his guilt in committing a crime is proven in the manner prescribed by law and established by a court verdict that has entered into legal force. A suspect, accused or defendant is not required to prove his innocence. All doubts about guilt, if the possibilities to eliminate them have been exhausted, should be resolved in favor of the suspect, accused or defendant. Also, in favor of the suspect, accused or defendant, doubts arising in the application of the law should be resolved.

Analysis of the above legislation on the presumption of innocence shows that this principle applies not only to the "suspect", "accused" or "defendant", but also to the right of every citizen of the Republic of Uzbekistan to be found guilty. on a specific criminal case.

Proofing is carried out by an inquiry officer, investigator, prosecutor, court. The suspect, the accused, the defendant, the defense attorney, the public prosecutor, the public defender, as well as the victim, civil plaintiff, civil defendant and their representatives have the right to participate in the proof. Witnesses, experts, specialists, translators, attesting witnesses, as well as other citizens and officials who, in order, exercise the rights and perform duties related to the collection, verification and assessment of evidence are involved in the proof.

It should also be noted that the cases provided for in part 3 of Article 23 of the Criminal Procedure Code are also important for the presumption of innocence. All doubts about guilt, if the possibilities to eliminate them have been exhausted, should be resolved in favor of the suspect, accused or defendant. Also, in favor of the suspect, accused or defendant, doubts arising from the application of the law should be resolved.

The norms of the presumption of innocence in the criminal procedural legislation of foreign countries: a comparative legal analysis. 
If we analyze the provisions on the presumption of innocence in the criminal procedural legislation of the Commonwealth of Independent States, then Article 14.1 of the Criminal Procedure Code of the Russian Federation states that "until the guilt of the accused is proved in accordance with the law; He was acquitted.

At the same time, in contrast to Article 23 of the Criminal Procedure Code of the Republic of Uzbekistan, the presumption of innocence, in addition to the accused, does not apply to suspects and defendants provided for in part 1 of Article 14 of the Criminal Procedure Code of the Russian Federation. Federation.

Similarly, Article 16 of the Criminal Procedure Code of the Republic of Belarus, entitled "Presumption of innocence", applies this principle only to the accused, including "until the defendant is found guilty of a crime in accordance with the law and the court's verdict is acquitted in strength ".

Article 8 of the Criminal Procedure Code of the Republic of Moldova states that "any person is presumed innocent until proven guilty in accordance with the law in an open trial with all the necessary guarantees for the protection of the person".

\section{Conclusion}

In conclusion, it is advisable to make the following proposals for improving the norms of the presumption of innocence in the country's criminal procedural legislation.

First, in order to directly ensure the right of innocence of any person whose guilt has not been proven by a court verdict, it is advisable to replace the concept of "suspect, accused or defendant" with the term "any person" in Article 23.1. Of the Criminal Procedure Code of Uzbekistan. After all, any citizen of the Republic of Uzbekistan, whose guilt has not been proven by an appropriate court document in the manner prescribed by law, has the right to protection from unfounded accusations.

Secondly, proceeding from the fact that the suspect, the accused, the defendant have the right to participate in the proof established by part 2 of Article 86 of the Criminal Procedure Code of the Republic of Uzbekistan, Article 23 of this Code. It is advisable to include in part 2 a clause stating that the suspect, accused or defendant is not obliged to prove his innocence, and then a clause stating that "they can also participate in proving in the manner established by this Code".

\section{References:}

1. Uralov, S. (2020). Some Issues Of Qualification Of The Rape Crime. Tsul Legal Report International Electronic Scientific Journal,

2. Uralov, S. (2020). Fight Against Corruption And The Shadow Economy - Guaranteeing The Rights And Freedoms Of Citizens. Review Of Law Sciences, 1 (Special).

3. Sarbon, U. (2020). Required Perspectives For Investigation Of Crimes In The Field Of Information Technology And Overcoming Crime. Review Of Law Sciences, (4).

4. Sardorovich, U. S. (2020). Some Issues Of Qualification Of The Rape Crime. Tsul Legal Report, $1(1)$.

5. Makhmudov, S. A. (2020). To Take Into Account Mitigating Circumstances When Imposing Punishment As One Of The Criteria For Imposing A Fair Penalty. In Progressive Technologies in the World Scientific Space (Pp. 154-158).

6. Maxmudov, S. A. Some Features Of To Take Into Account Mitigating Circumstances For Imposing A Fair Penalty.

7. Махмудов, С. (2020). Some Aspects of Terminating a Criminal Case Without Resolving the Guilt Case. Lawyer's Bulletin, 1 (6), 110-115.8. 
8. Bazarova, D. Crime Prevention And Prevention: A Comparative Analysis.

9. Bazarova, D. Phd In Law, Professor Of Tashkent State University Of Law E-Mail: Dildora@ Me. Com.

10. Bazarova, D. On Assurance Of Rights And Interests Of The Victim In Criminal Proceedings Of The Republic Of Uzbekistan.

11. Bazarova, D. Legal Tech: Law And Information Technology.

12. Bazarova, D. (2016). Procedural Provision of Guarantees in Criminal Proceedings (Based on the Materials of the Republic of Uzbekistan). Actual Problems of Modern Science, (3), 88-92.

13. Bazarova, D. (2020). Selected Aspects of Implementation of International Standards by Improving the Criminal Procedure Form. Review Of Law Sciences, 2 (Special Issue).

14. Bazarova, D. (2021). Guarantees Of The Rights Of Other Persons In Criminal Procedure In The Case Of Covid 19. Annals Of The Romanian Society For Cell Biology, 6337-6346.

15. Bazarova, D. (2021). Challenges Of Enhancement Of The Procedural Guarantees Of The Rights And Interests Of Participants In Criminal Proceedings. Ilkogretim Online, 20(3).

16. Bazarova, D. B. (2016). Place And Role Of Procedural Safeguards In Criminal Procedure. In State And Law. Actual Scientific Problems. Consideration, Decision, Practice (Pp. 50-53).

17. Bazarova, D. (2019). The Use Of The Institution Of Consignation Of Testimony As A Proceduralguarantee To Protect The Rights And Legitimate Interests Of Participants In Criminal Procedure. European Journal Of Business And Social Sciences, 7(5), 742-751.

18. Bazarova, D. B. (2016). Procedural Safeguards In Investigating And Adjudicating Criminal Cases By Summary Procedure. Theoretical \& Applied Science, (12), 34-37.

19. Bazarova, D. (2020). Principles Of Criminal Procedure In The System Of Guaranteeing The Rights Of Participants In Criminal Court Proceedings. The American Journal Of Social Science And Education Innovations, 2(02).

20. Bazarova, D. (2020). The Role of the Prosecutor in Ensuring the Guarantees of the Rights and Freedoms of Participants in Criminal Proceedings. Review Of Law Sciences, (3).

21. Bazarova, D. (2020). About The System Of Procedural Guarantees To Ensure The Rights Of Participants In Criminal Proceedings. International Journal Of Psychosocial Rehabilitation, 24(2).

22. Bazarova, D., \& Utarov, K. (2021). Comparative Legal Analysis Of Issues Of Enforcement Of Rights Of Individuals In The Criminal Proceeding Of The Republic Of Uzbekistan And Republic Of Kazakhstan. The American Journal Of Political Science Law And Criminology, 3(02), $105-$ 110.

23. Bazarova, D. B. (2017). Right to Defense as a Procedural Guarantee in the Criminal Proceedings of the United States. Legal Research, (3), 17-22.

24. Bazarova, D. (2019). Application of the Institute for the Deposition of Testimony as a Procedural Guarantee for the Protection of the Rights and Legal Interests of the Participants of the Criminal Procedure. Law And Life, (1), 157-167.

25. Bazarova, D. B. (2016). The Principle Of Respect For The Honor And Dignity Of The Person As The Most Important Procedural Guarantee In Criminal Proceedings. Russian Investigator, (20), 53-56.

26. Bazarova, D. (2019). Some Problems Of Counteracting Crimes Related To Laundering Of Illegal Proceeds In Uzbekistan. Journal Of Advanced Research In Dynamical And Control Systems, 11(7), 873-885. 